\begin{tabular}{|c|c|c|}
\hline 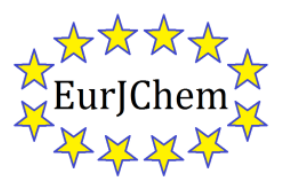 & $\begin{array}{c}\text { European Journal of Chemistry } \\
\text { Journal homepage: } \underline{w w w . e u r j c h e m . c o m ~}\end{array}$ & 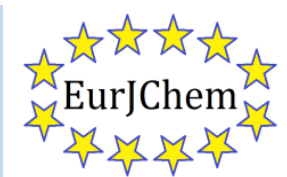 \\
\hline
\end{tabular}

\title{
Flotation, speciation and determination of iron(III) using aluminon in water, real samples and wastes of power stations
}

\author{
Ahmed Fawzy El-Asmy*a, Wafaa Mohammad Yousef ${ }^{\mathrm{b}}$ and Magda Ali Akla \\ a Chemistry Department, Faculty of Science, Mansoura University, 35516, Egypt \\ b Chemistry Department, Faculty of Science, Hail University, 81428, Saudi Arabia \\ *Corresponding author at: Chemistry Department, Faculty of Science, Mansoura University, 35516, Egypt. Tel.: +20101645966; fax: +20502246781.

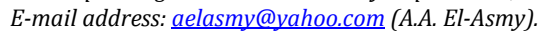

\section{ARTICLE INFORMATION}

Received: 30 April 2010

Received in revised form: 31 May 2010

Accepted: 6 June 2010

Online: 30 September 2010

\section{KEYWORDS}

\section{Iron(III)}

Speciation

Determination

Flotation

\section{Introduction}

Iron occurs with molybdenum in enzymes that catalyze nitrogen fixation [1]. The preconcentration and determination of iron in different oxidation states are the aim of many workers, especially in environmental chemistry, industrial food, agriculture and pharmaceutical clinical control [2]. In this concern, numerous techniques for the separation and preconcentration of trace metals have been reported [3-8]. Flotation has many advantages owing to simplicity, time saving, non expensive reagents and apparatus and incorporated as a clean technology to treat water and wastewater [9]. Few publications deals with the separation of Fe(III) from Fe(II) [10]. Although the separation of Fe(III) by ion and precipitate flotation [11-16] was carried out, no trial was made to use aluminon in this respect.

Heavy metal pollution is spreading throughout the world with the expansion of industrial activities [17]. These metals, which find many useful applications, are harmful if they are discharged into natural water resources with serious health hazards [18-20]. In other words, heavy metals which are of great environmental concern must be removed [21-23]. Industrial wastewater contains high levels of heavy metals and to avoid water pollution, treatment is needed before disposal.

In the present work, flotation and speciation of Fe(III) using aluminon and HOL were proposed. Experimental variables were examined. In addition, Fe(III) determination in synthetic, real samples, different water samples and wastes from power stations was carried out.

\section{Experimental}

\subsection{Chemicals and solutions}

Unless otherwise stated, all chemicals used in this study were of analytical grade or high purity. Aluminon $\left[\mathrm{C}_{22} \mathrm{H}_{23} \mathrm{~N}_{3} \mathrm{O}\right.$ 9 solution $\left[1 \times 10^{-2} \mathrm{~mol} \mathrm{~L}^{-1}\right]$ (Scheme 1) was prepared by dissolving $0.47 \mathrm{~g}$ in $100 \mathrm{~mL}$ bidistilled water. Oleic acid $\left[6.36 \times 10^{-2} \mathrm{~mol} \mathrm{~L}^{-1}\right]$ was prepared by dispersing $20 \mathrm{~mL}$ in $1 \mathrm{~L}$ kerosene. Fe(III) $\left[1 \times 10^{-2} \mathrm{~mol} \mathrm{~L}^{-1}\right]$ was taken from the standard solution. Fe(II) $\left[1 \times 10^{-2} \mathrm{~mol} \mathrm{~L}^{-1}\right]$ was prepared from $\mathrm{FeSO}_{4} .7 \mathrm{H}_{2} \mathrm{O}$ in $100 \mathrm{~mL}$; the solution must be freshly prepared. A stock solution of $1 \times 10^{-2} \mathrm{~mol} \mathrm{~L}^{-1}$ EDTA was prepared by dissolving $3.74 \mathrm{~g}$ in $1 \mathrm{~L}$ bidistilled water and standardized. A $0.1 \mathrm{~mol} \mathrm{~L}^{-1}$ of oxalic, $\mathrm{HNO}_{3}, \mathrm{NH}_{4} \mathrm{OH}$ and $\mathrm{Pb}\left(\mathrm{NO}_{3}\right)_{2}$, each, was prepared by dissolving the calculated weight in $100 \mathrm{~mL}$ solution. Diluted concentrations of $\mathrm{NaF}, \mathrm{NH}_{4} \mathrm{SCN}$ and $\mathrm{NaBH}_{4}$ were prepared from stock solutions of $0.1 \mathrm{~mol} \mathrm{~L}^{-1}$ of $\mathrm{NaF}, \mathrm{NH}_{4} \mathrm{SCN}$ and $10 \mathrm{mg} \mathrm{L}^{-1}$ of $\mathrm{NaBH}_{4}$.<smiles>NC(=O)c1cc(C(=C2C=CC(=O)C(C(=O)O)C2)c2ccc(O)c(C(=O)O)c2)ccc1O</smiles>

Scheme 1 


\subsection{Instrumentation}

Two flotation cells were used. The first was a tube of $1.2 \mathrm{~cm}$ inner diameter and $29 \mathrm{~cm}$ length with a stopcock at the bottom. Such a cell was used during the study of the factors affecting the efficiency of flotation. The second was a cylindrical tube of $6 \mathrm{~cm}$ inner diameter and $45 \mathrm{~cm}$ length with a stopcock at the bottom and a quick-fit stopper at the top. It was used for the separation of the investigated analyte from a relatively large volume. The spectrophotometric data were recorded on a Unicam $U_{2}$ spectrophotometer. The concentrations of Fe were determined using a Perkin Elmer 2380 Atomic Absorption Spectrometer with air-acetylene flame. The optimum instrumental parameters used are: wavelength: $248.3 \mathrm{~nm}$; lamp current: $25 \mathrm{~mA}$; Fuel flow rate: $3 \mathrm{~L} \mathrm{~min}^{-1}$; air flow rate: $21 \mathrm{~L}$ min $^{-1}$; burner height: $0.9 \mathrm{~cm}$ and slit width: $0.7 \mathrm{~nm}$. The IR spectra of aluminon and its solid complexes were recorded on a Mattson 5000 FTIR spectrophotometer. The pH values of all solutions prepared before flotation were carried out using HANA instrument 8519 digital pH-meter (Italy). The mass spectra of the Fe(III) complex was measured at $70 \mathrm{eV}$ with a Varian MAT 311 instrument at National Research Center, Cairo. Magnetic measurements were carried out on a JohnsonMatthey magnetic susceptibility balance, UK. Carbon and hydrogen content for the formed aluminon-Fe(III) complexes was determined at the Microanalytical Unit, Cairo University, Egypt. The Fe analysis was carried out according to the standard methods [24].

\subsection{Preparations}

Aluminon (Scheme 1) is provided from Riedel-de Haen, Germany. The solid complex, in aqueous solution, was prepared by mixing equimolar amounts of aluminon and Fe(III) ions in $\mathrm{H}_{2} \mathrm{O}$-EtOH solution. The colored solid complex that precipitated was filtered off and dried under vacuum. On the other hand, the complex in the scum layer was obtained by gathering the float layer in some flotation experiments (equimolar amounts of aluminon and Fe(III) ions in presence of $3 \mathrm{~mL} \mathrm{HOL})$. The float was filtered, washed with bidistilled water and ethanol, dried in oven at $80^{\circ} \mathrm{C}$ and preserved in a desiccator.

\subsection{Separation-determination of Fe(III) and Fe(II)}

Suitable concentration $\left(2 \times 10^{-5} \mathrm{~mol} \mathrm{~L}^{-1}\right)$ of $\mathrm{Fe}(\mathrm{III})$ and $\mathrm{Fe}(\mathrm{II})$, $0.5 \mathrm{mg} \mathrm{L}^{-1}$ of $\mathrm{NaBH}_{4}$ and aluminon $\left(2 \times 10^{-4} \mathrm{~mol} \mathrm{~L}^{-1}\right)$ were introduced into a flotation cell. The $\mathrm{pH}$ of the solution was adjusted to $\approx 2$ by adding drops of $0.1 \mathrm{~mol} \mathrm{~L}^{-1} \mathrm{HCl}$. The cell was shaken manually for about $2 \mathrm{~min}$, after which $3 \mathrm{~mL}$ of $2 \times 10^{-3}$ mol L-1 HOL were added. The cell was then turned upside down many times by hand for complete flotation of Fe(III)-aluminon species. The mother liquor was separated from the flotation cell and then introduced into the AAS flame for measurement of $\mathrm{Fe}(\mathrm{II})$. The floatability of $\mathrm{Fe}(\mathrm{II})$ was obtained from the relationship:

$$
F_{F e(I I)}=\frac{C_{i}-C_{f}}{C_{i}} x 100 \%
$$

$C_{i}$ and $C_{f}$ denote the initial and final concentrations of Fe(II). Subsequently, $2 \mathrm{~mL}$ of conc. $\mathrm{HCl}$ were added to the scum inside the flotation cell and the mixture was shaken thoroughly to extract the Fe(III) from the scum. The extract was made up to a suitable volume having a final concentration of $2 \times 10^{-4} \mathrm{~mol} \mathrm{~L}^{-1}$ of aluminon. The $\mathrm{Fe}(\mathrm{III})$ was measured by AAS against a standard Fe(III) solution containing the same concentration of aluminon. The efficiency of flotation of the Fe(III) in the scum was determined from the relationship:
$\mathrm{F}_{\mathrm{Fe}(I I I)}=\left(\mathrm{C}_{\mathrm{s}} / \mathrm{C}_{\mathrm{i}}\right) \times 100 \%$

$\mathrm{C}_{\mathrm{s}}$ denote the concentration of $\mathrm{Fe}(\mathrm{III})$ in the scum. Titrimetric procedure for determination of Fe(III): To a conical flask, add $5 \mathrm{~mL}$ of $\mathrm{Fe}(\mathrm{III})$ solution, $20 \mathrm{~mL}$ bidistilled water, 5 $\mathrm{mL}$ of $0.01 \mathrm{~mol} \mathrm{~L}^{-1}$ EDTA, two drops of xylenol orange and hexamine, then titrate against $0.01 \mathrm{~mol} \mathrm{~L}^{-1} \mathrm{~Pb}\left(\mathrm{NO}_{3}\right)_{2}$ [24]

\subsection{Applications}

Synthetic mixtures: Into a flotation cell, $1.12 \mathrm{ppm}$ of Fe(III) was taken and strict concentration was added from each foreign ion individually or in combination in presence of $2 \times 10^{-4}$ molL-1 aluminon in $\mathrm{Fe}(\mathrm{III})$ separation. The procedures for flotation, separation, elution and spectrophotometric (atomic absorption) determination were carried out.

Natural water samples: To $100 \mathrm{~mL}$ aliquot of clean uncontaminated, filtered natural water samples, different concentrations of the investigated analyte were introduced with excess aluminon. The previous procedures of separation and determination were carried out.

Real samples: Lead-zinc sulfide and stream sediment ores [25] were provided from National Center of Metrology. Accurately $0.5 \mathrm{~g}$ solid sample was completely dissolved in Teflon beaker with mixture of acids ( $45 \mathrm{~mL} \mathrm{HF}, 15 \mathrm{~mL} \mathrm{H}_{2} \mathrm{SO}_{4}$ and $5 \mathrm{~mL} \mathrm{HNO}_{3}$ ). After complete dissolution, the solution was evaporated till dryness. The residue was then dissolved in $20 \mathrm{~mL} \mathrm{HCl} \mathrm{(1:1)} \mathrm{and}$ completed to $100 \mathrm{~mL}$ in a measuring flask with bidistilled water.

\section{Results and Discussion}

\subsection{Separation and determination of Fe(III)}

The separation-flotaion of Fe(III) enabling one to apply this new technique on waste samples taken from the power stations before discharge. This followed by studying the separation of $\mathrm{Fe}(\mathrm{II})$ from $\mathrm{Fe}(\mathrm{III})$ and modifying an analytical method for determination of both in one sample.

\subsubsection{Influence of the hydrogen ion concentration}

A series of experiments were carried out to study the effect of $\mathrm{pH}$ on the flotation efficiency of $\mathrm{Fe}(\mathrm{III})\left[2 \times 10^{-5} \mathrm{~mol} \mathrm{~L}^{-1}\right]$ with $2 \times 10^{-3} \mathrm{~mol} \mathrm{~L}^{-1} \mathrm{HOL}$ in absence and presence of $1 \times 10^{-4} \mathrm{~mol} \mathrm{~L}^{-1}$ aluminon. Figure $1 \mathrm{~b}$ shows that about $45 \%$ is the maximum separation efficiency at $\mathrm{pH} 2-3$. Accordingly, the separation of $\mathrm{Fe}(\mathrm{III})$ needs modification. Aluminon imposed itself as a good chelating agent. Figure $1 \mathrm{a}$ shows that $\approx 100 \%$ efficiency was obtained at $\mathrm{pH} 2-3$. In basic medium, the separation decreases due to the formation of oleate. Direct addition of ferric ammonium sulfate and aluminon acquires $\mathrm{pH} \approx 3$.

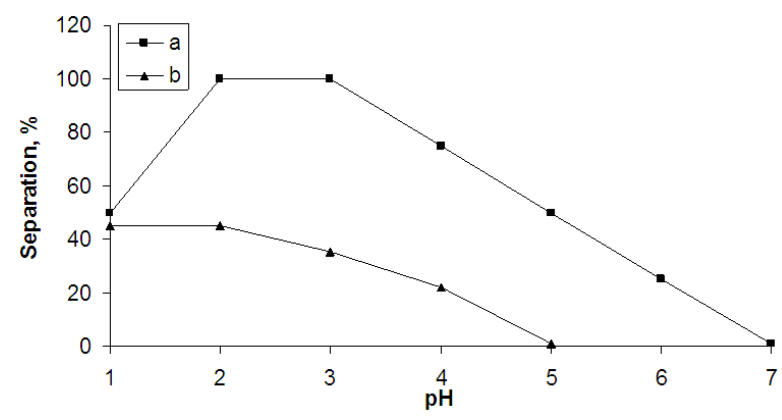

Figure 1. Effect of $\mathrm{pH}$ on the separation efficiency of $2 \times 10^{-5} \mathrm{~mol} \mathrm{~L}^{-1} \mathrm{Fe}(\mathrm{III})$ using $2 \times 10^{-3} \mathrm{~mol} \mathrm{~L}^{-1} \mathrm{HOL}$ without aluminon (curve a) and with $1 \times 10^{-4}$ mol L-1 aluminon (curve b). 


\subsubsection{Influence of interacting species concentrations}

The effect of Fe(III), aluminon and HOL is investigated. Figure 2 show that the floatability of Fe(III) increases reaching $100 \%$ at $2 \times 10^{-5} \mathrm{~mol} \mathrm{~L}^{-1}$ aluminon with molar ratio of $1: 1$ at $\mathrm{pH}$ $\approx 3$. This simplified the procedure for the analytical separation and determination of Fe(III), specially in samples containing unknown amounts of $\mathrm{Fe}(\mathrm{III})$; the selected concentration of aluminon for further experiments was $1 \times 10^{-4} \mathrm{~mol} \mathrm{~L}^{-1}$.

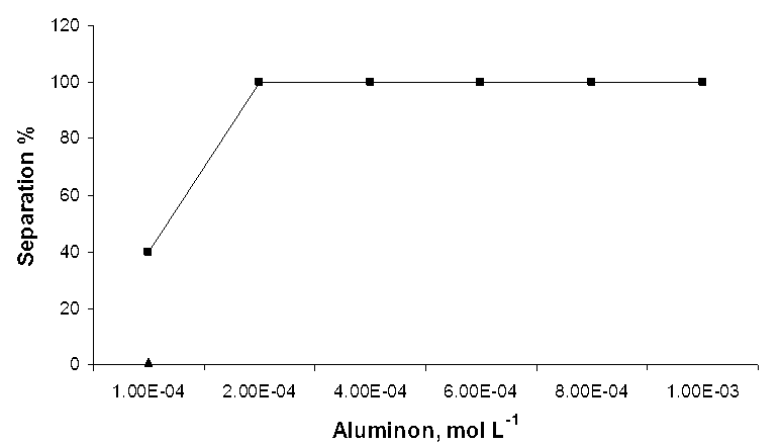

Figure 2. Effect of aluminon concentration on the separation efficiency of $2 \times 10^{-5} \mathrm{~mol} \mathrm{~L}^{-1} \mathrm{Fe}(\mathrm{III})$ at $\mathrm{pH} \approx 3$ using $2 \times 10^{-3} \mathrm{~mol} \mathrm{~L}^{-1} \mathrm{HOL}$

Figure $3 \mathrm{a}$ represents the separation percentage of $\mathrm{Fe}(\mathrm{III})$ using $2 \times 10^{-3} \mathrm{~mol} \mathrm{~L}^{-1} \mathrm{HOL}$ at $\mathrm{pH} \approx 3$ in absence of aluminon. The percentage is $\approx 45 \%$ and by increasing the analyte concentration, the floatability decreases owing to the presence of insufficient amounts of oleate capable for floating all the present $\mathrm{Fe}(\mathrm{III})$ ions. Also, to confirm the data in Figure 2, another series of experiments were carried out to float different amounts of Fe(III) ions. In Figure 3b, the separation percentage achieved $100 \%$ corresponding to the $1: 1 \mathrm{Fe}(\mathrm{III})$ : aluminon ratio.

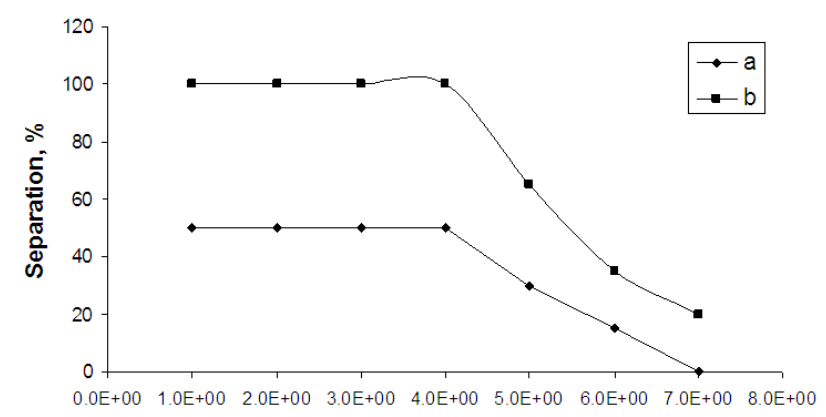

[Fe(III)], $\mathrm{mol} \mathrm{L}^{-1}$

Figure 3. Separation efficiency of different $\mathrm{Fe}(\mathrm{III})$ concentrations at $\mathrm{pH} \approx 3$ in absence (curve a) and presence of $2 \times 10^{-5} \mathrm{~mol} \mathrm{~L}^{-1}$ aluminon (curve b) using $2 \times 10^{-3} \mathrm{~mol} \mathrm{~L}^{-1} \mathrm{HOL}$

The floatability of Fe(III) at different concentrations of HOL in absence (Figure 4, curve a) and presence (Figure 4, curve b) of aluminon was investigated. Curve (a) shows $45 \%$ floatability even at different concentrations of HOL. Curve $b$ shows $\approx 100 \%$ floatability of $\mathrm{Fe}(\mathrm{III})$ at $10^{-4} \mathrm{~mol} \mathrm{~L}^{-1}$ of $\mathrm{HOL}$ and remains constant. Accordingly, $2 \times 10^{-3} \mathrm{~mol} \mathrm{~L}^{-1} \mathrm{HOL}$ was used throughout the work.

Spectrophotometric measurements were carried out to assure the data obtained in Figures 2 and 3. The absorption spectra of $\mathrm{Fe}(\mathrm{III})$, aluminon and $\mathrm{Fe}(\mathrm{III})$-aluminon systems showed that aluminon and $\mathrm{Fe}(\mathrm{III})$ have no absorption bands at the wavelength range of $\mathrm{Fe}(\mathrm{III})$-aluminon. The aqueous complex shows a band centered at $580 \mathrm{~nm}$. The stoichiometry of the complex formed was ascertained applying the continuous variation method. The results revealed the formation of 1:1 [Fe(III)-aluminon] ratio. The apparent formation constant $\left(\mathrm{K}_{\mathrm{f}}\right)$ of the complex is $1.3 \times 10^{7} \mathrm{~L} \mathrm{~mol}^{-1}$.

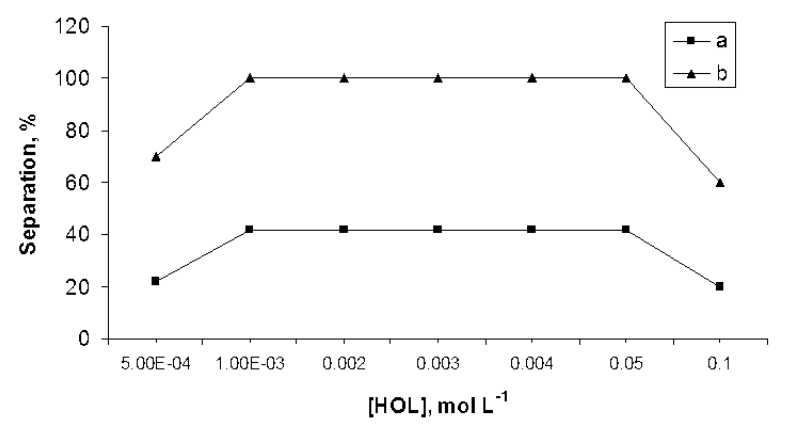

Figure 4. Influence of HOL concentration on the separation efficiency of $2 \times 10^{-5} \mathrm{~mol} \mathrm{~L}^{-1} \mathrm{Fe}$ (III) in absence of aluminon (curve a) and in presence of $1 \times 10^{-4} \mathrm{~mol} \mathrm{~L}^{-1}$ (curve b) at $\mathrm{pH} \approx 3$.

\subsubsection{Influence of volume}

Series of experiments were conducted to float different quantities of $\mathrm{Fe}(\mathrm{III})$ in a fixed volume $(10 \mathrm{~mL})$ under the recommended conditions. It was found that the smallest amount of the analyte which can be safely and quantitatively separated from $10 \mathrm{~mL}$ is $2 \times 10^{-5} \mathrm{~mol} \mathrm{~L}^{-1}$. Another series of experiments were conducted to float a fixed concentration of the analyte $\left(2 \times 10^{-3} \mathrm{~mol} \mathrm{~L}^{-1}\right)$ from different aqueous volumes using suitable large flotation cells under the recommended conditions. The data showed that $1 \times 10^{-3} \mathrm{~mol} \mathrm{~L}^{-1}$ of Fe(III) can be quantitatively separated from different aqueous volumes up to $2 \mathrm{~L}$ after which, the floatability decreases by $30 \%$ at $2.5 \mathrm{~L}$. Accordingly, the detection limit of separation procedure is 0.56 ppm.

\subsubsection{Influence of temperature}

Solutions of Fe(III), HOL and aluminon were either heated or cooled. The aluminon and HOL are quickly poured into the $\mathrm{Fe}(\mathrm{III})$ solution at zero time. The solution was introduced into flotation cell jacked with $1 \mathrm{~cm}$ thick fiberglass insulation at $\mathrm{pH}$ $\approx 3$. The data indicated that temperature up to $60{ }^{\circ} \mathrm{C}$ has no effect on the flotation process. Hence, subsequent experiments were carried out at $25 \pm 1{ }^{\circ} \mathrm{C}$.

\subsubsection{Influence of ionic strength}

The effect of ionic strength on the separation efficiency of $\mathrm{Fe}(\mathrm{III})$ under the recommended conditions (Table 1) indicated that, $\mathrm{Na}^{+}, \mathrm{K}^{+}, \mathrm{Mg}^{2+}$ and $\mathrm{Ca}^{2+}$ as $\mathrm{Cl}^{-}, \mathrm{NO}_{3}{ }^{-}, \mathrm{SO}_{4}{ }^{2-}, \mathrm{NO}_{2}^{-}$and/or Iadded during the flotation separation of the analyte have no effect up to $0.5 \mathrm{~mol} \mathrm{~L}^{-1}$ concentration level.

Table 1. Effect of ionic strength on the separation efficiency of $2 \times 10^{-5} \mathrm{~mol} \mathrm{~L}^{-1}$ Fe(III) using $2 \times 10^{-4} \mathrm{~mol} \mathrm{~L}^{-1}$ aluminon and $2 \times 10^{-3} \mathrm{~mol} \mathrm{~L}{ }^{-1} \mathrm{HOL}$ at $\mathrm{pH} \approx 3$.

\begin{tabular}{lll}
\hline Cation* & Concentration, $\mathbf{~ m o l ~ L}^{-1}$ & Recovery, $\%$ \\
\hline \multirow{2}{*}{$\mathrm{Na}^{+}$} & 0.50 & 99.8 \\
& 0.10 & 99.9 \\
& 0.05 & 99.9 \\
$\mathrm{~K}^{+}$ & 0.50 & 98.9 \\
& 0.10 & 98.9 \\
& 0.05 & 99.5 \\
$\mathrm{Mg}^{2+}$ & 0.50 & 99.5 \\
& 0.10 & 99.5 \\
& 0.05 & 99.7 \\
$\mathrm{Ca}^{2+}$ & 0.50 & 98.8 \\
& 0.10 & 98.8 \\
& 0.05 & 99.4 \\
\hline
\end{tabular}

${ }^{*} \mathrm{Na}^{+}, \mathrm{K}^{+}, \mathrm{Mg}^{2+}$ and $\mathrm{Ca}^{2+}$ were taken as $\mathrm{Cl}^{-}, \mathrm{SO}_{4}{ }^{2-}$ or $\mathrm{NO}_{3}{ }^{-}$. 


\subsubsection{Effect of foreign ions}

The data presented in Table 2 showed that, the investigated interfering ions up to $50 \mathrm{mg} \mathrm{L}^{-1}$ (each) individually or in combination have no pronounced effect on the separation efficiency of Fe(III) even on using $2 \times 10^{-4} \mathrm{~mol} \mathrm{~L}^{-1}$ aluminon. The interfering species present with $\mathrm{Fe}(\mathrm{III})$ depress the separation efficiency; excess aluminon overcome this effect.

Table 2. Effect of some foreign ions individually or in combinations on the separation efficiency of $2 \times 10^{-5} \mathrm{~mol} \mathrm{~L}^{-1}$ of $\mathrm{Fe}(\mathrm{III})$ in presence of different aluminon concentrations using $2 \times 10^{-3} \mathrm{~mol} \mathrm{~L}^{-1} \mathrm{HOL}$ at $\mathrm{pH} \approx 3$.

\begin{tabular}{|c|c|c|c|}
\hline \multirow[b]{2}{*}{ Foreign ion(s) } & \multirow[b]{2}{*}{$\begin{array}{l}\text { Concent., } \\
\text { mg L L-1 }^{-1}\end{array}$} & \multicolumn{2}{|c|}{ Recovery \% } \\
\hline & & $\begin{array}{l}\text { Using } 1 \times 10^{-4} \\
\text { mol } \mathrm{L}^{-1} \\
\text { aluminon }\end{array}$ & $\begin{array}{l}\text { Using } 2 \times 10^{-4} \\
\text { mol } \mathrm{L}^{-1} \\
\text { aluminon }\end{array}$ \\
\hline $\mathrm{Cu}(\mathrm{II})$ & 1000 & 100.0 & 100.0 \\
\hline $\mathrm{Pb}(\mathrm{II})$ & 1000 & 99.5 & 99.9 \\
\hline $\mathrm{Ni}(\mathrm{II})$ & 1000 & 99.8 & 99.9 \\
\hline $\mathrm{Hg}(\mathrm{II})$ & 1000 & 99.7 & 99.9 \\
\hline $\mathrm{Ca}(\mathrm{II})$ & 1000 & 99.9 & 100.0 \\
\hline $\operatorname{Ag}(I)$ & 500 & 99.9 & 99.9 \\
\hline $\mathrm{Li}(\mathrm{I})$ & 500 & 99.9 & 100.0 \\
\hline $\mathrm{La}(\mathrm{III})$ & 500 & 99.7 & 99.8 \\
\hline Cd(II) & 500 & 99.8 & 99.9 \\
\hline $\mathrm{Mg}(\mathrm{II})$ & 500 & 99.7 & 99.9 \\
\hline $\mathrm{Te}(\mathrm{II})$ & 500 & 99.8 & 99.9 \\
\hline Mn(II) & 500 & 60.0 & 100.0 \\
\hline $\operatorname{Sr}(I I)$ & 100 & 99.9 & 100.0 \\
\hline $\mathrm{Co}(\mathrm{II})$ & 100 & 85.0 & 100.0 \\
\hline $\mathrm{Al}(\mathrm{III})$ & 100 & 80.0 & 100.0 \\
\hline Th(IV) & 50 & 99.7 & 99.8 \\
\hline W(III) & 50 & 99.8 & 99.9 \\
\hline V(IV) & 50 & 99.6 & 99.8 \\
\hline $\operatorname{Cr}(I I I)$ & 50 & 99.7 & 99.8 \\
\hline Mo(III) & 50 & 99.8 & 99.9 \\
\hline Sn(IV) & 50 & 99.8 & 99.9 \\
\hline In(III) & 50 & 99.7 & 99.8 \\
\hline As(III) & 50 & 99.9 & 99.9 \\
\hline $\mathrm{Zn}(\mathrm{II})$ & 50 & 75.0 & 99.9 \\
\hline $\mathrm{Zr}(\mathrm{IV})$ & 50 & 69.0 & 99.9 \\
\hline $\mathrm{Cu}(\mathrm{II})+\mathrm{Mg}(\mathrm{II})$ & 500 & 99.7 & 99.8 \\
\hline $\mathrm{Cu}(\mathrm{II})+\mathrm{Ca}(\mathrm{II})$ & 500 & 99.9 & 100.0 \\
\hline $\mathrm{Ni}(\mathrm{II})+\mathrm{Ag}(\mathrm{I})$ & 500 & 99.8 & 99.9 \\
\hline $\mathrm{La}(\mathrm{III})+\mathrm{Ti}(\mathrm{IV})$ & 500 & 99.8 & 99.9 \\
\hline $\mathrm{Cu}(\mathrm{II})+\mathrm{Ca}(\mathrm{II})+\mathrm{Mg}(\mathrm{II})$ & 500 & 99.7 & 99.8 \\
\hline $\mathrm{Cu}(\mathrm{II})+\mathrm{Ca}(\mathrm{II})+\mathrm{Hg}(\mathrm{II})$ & 500 & 99.8 & 99.9 \\
\hline $\mathrm{Cd}(\mathrm{II})+\mathrm{Ca}(\mathrm{II})+\mathrm{La}(\mathrm{III})$ & 500 & 99.8 & 99.9 \\
\hline $\mathrm{Ni}(\mathrm{II})+\mathrm{Pb}(\mathrm{II})+\mathrm{Li}(\mathrm{I})$ & 500 & 99.7 & 99.8 \\
\hline $\mathrm{Te}(\mathrm{II})+\mathrm{Mg}(\mathrm{II})+\mathrm{La}(\mathrm{III})$ & 500 & 99.8 & 99.9 \\
\hline $\mathrm{Cu}(\mathrm{II})+\mathrm{Sr}(\mathrm{II})$ & 100 & 99.9 & 99.9 \\
\hline $\mathrm{Co}(\mathrm{II})+\mathrm{Sr}(\mathrm{II})$ & 100 & 80.0 & 99.9 \\
\hline $\mathrm{Al}(\mathrm{III})+\mathrm{Th}(\mathrm{IV})$ & 50 & 99.8 & 99.9 \\
\hline $\mathrm{Cu}(\mathrm{II})+\mathrm{W}(\mathrm{III})$ & 50 & 99.7 & 99.9 \\
\hline $\mathrm{Cu}(\mathrm{II})+\mathrm{Cr}(\mathrm{III})+\mathrm{Zn}(\mathrm{II})$ & 50 & 75.0 & 99.9 \\
\hline $\mathrm{Zn}(\mathrm{II})+\mathrm{V}(\mathrm{IV})+\mathrm{Ni}(\mathrm{II})$ & 50 & 80.0 & 99.8 \\
\hline
\end{tabular}

\subsection{Separation of $\mathrm{Fe}(\mathrm{II})$ from $\mathrm{Fe}(\mathrm{III})$}

None of the freshly prepared Fe(II) that exposed to air gave results different from that of less exposed; freshly prepared is also studied. The same previous results are obtained, but with slight decrease in flotation. This observation leads to think that aluminon can oxidize part of $\mathrm{Fe}(\mathrm{II})$ to $\mathrm{Fe}(\mathrm{III})$ forming $\mathrm{Fe}(\mathrm{III})$ complex until all Fe(II) are oxidized. The process is followed sequentially till all Fe(II) is complexed completely. The data depicted in Figure 5 showed zero separation up to $25 \mathrm{~min}$ and increases gradually reaching $100 \%$ in $1 \mathrm{~h}$. Complete separation and oxidation of $\mathrm{Fe}(\mathrm{II})$ within $1 \mathrm{~h}$ is due to its little concentration $\left(2 \times 10^{-5} \mathrm{~mol} \mathrm{~L}^{-1}\right)$. The separation of Fe(II) was carried out within $25 \mathrm{~min}$. Also, the spectral measurements confirm that freshly prepared Fe(II) was not floated even in the presence of aluminon which may be due to the unstability of $\mathrm{Fe}(\mathrm{II})$ - aluminon complex. Consequently, the isolation of Fe(II) must be carried out in absence of air.

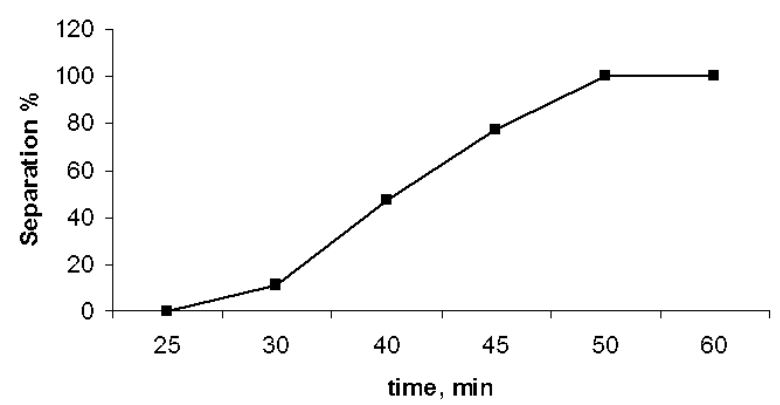

Figure 5. Effect of time on the separation percentage of $2 \times 10^{-5} \mathrm{~mol} \mathrm{~L}^{-1}$ $\mathrm{Fe}(\mathrm{II})$ at $\mathrm{pH} \approx 3$ in presence of $1 \times 10^{-4} \mathrm{~mol} \mathrm{~L}^{-1}$ aluminon and $2 \times 10^{-3} \mathrm{~mol} \mathrm{~L}^{-1}$ HOL.

Trials to separate $\mathrm{Fe}(\mathrm{II}) / \mathrm{Fe}(\mathrm{III})$ using $\mathrm{NH}_{4} \mathrm{SCN}$ or $\mathrm{NaF}$ have been carried out. Figure 6 shows the influence of $\mathrm{NaF}$ on the separation speciation in which there is a gradual increase in the separation curve of Fe(II) due to partial oxidation with time forming a complex giving a maximum at $25 \%$. On the other hand, the separation curve of Fe(III) decreases gradually due to its existence as unfloated $\left[\mathrm{FeF}_{6}\right]^{3-}$. So, $\mathrm{Fe}(\mathrm{III})$-aluminon, $\left[\mathrm{FeF}_{6}\right]^{3-}$ and oxidized Fe(II) reflect incomplete separation.

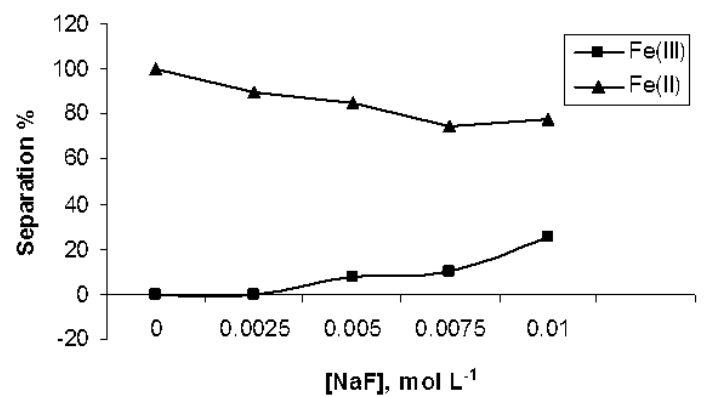

Figure 6. Effect of $[\mathrm{NaF}]$ on the separation efficiency of a mixture $\left(2 \times 10^{-5} \mathrm{~mol} \mathrm{~L}^{-1}\right)$ of $\mathrm{Fe}(\mathrm{III})$ and $\mathrm{Fe}(\mathrm{II}),\left(2 \times 10^{-5} \mathrm{~mol} \mathrm{~L}^{-1}\right)$ each, in presence of $2 \times 10^{-4} \mathrm{~mol} \mathrm{~L}^{-1}$ aluminon using $2 \times 10^{-3} \mathrm{~mol} \mathrm{~L}^{-1} \mathrm{HOL}$ at $\mathrm{pH} \approx 3$.

The data obtained in the presence of $\mathrm{NH}_{4} \mathrm{SCN}$ showed a decrease in the separation of Fe(III) due to the presence of Fe(III)-aluminon and Fe(III)-thiocyanate complexes. The separation of $\mathrm{Fe}(\mathrm{II})$ increases up to $40 \%$ due to partial oxidation of $\mathrm{Fe}(\mathrm{II})$ forming Fe(III)-aluminon and Fe(III)thiocyanate. The incomplete separation is due to the presence of Fe(III)-thiocyante float and the already formed Fe(III)aluminon and the oxidized part of Fe(II). So, the separation is not selective. Trials to achieve complete separation of Fe(III) from $\mathrm{Fe}(\mathrm{II})$ were carried out by the previous two experiments using equal concentrations of $\mathrm{Fe}(\mathrm{III})$, aluminon and $\mathrm{Fe}(\mathrm{II})$, $\left(2 \times 10^{-5} \mathrm{~mol} \mathrm{~L}^{-1}\right)$ each, using $2 \times 10^{-3} \mathrm{~mol} \mathrm{~L}^{-1} \mathrm{HOL}$ at $\mathrm{pH} \approx 3$ in presence of $\mathrm{NaF}$ or $\mathrm{NH}_{4} \mathrm{SCN}$. The ratio of $1: 1$ (Fe(III)-aluminon) assure that all aluminon reacted with Fe(III) and nothing with the partially oxidized Fe(II).

The trials focused on using $\mathrm{NaBH}_{4}$ with different concentrations to show the effect of time on the separation percentage of $2 \times 10^{-5} \mathrm{~mol} \mathrm{~L}^{-1} \mathrm{Fe}(\mathrm{II})$ in the presence of $1 \times 10^{-4}$ mol L-1 aluminon and $2 \times 10^{-3} \mathrm{~mol} \mathrm{~L}^{-1} \mathrm{HOL}$ at $\mathrm{pH} \approx 2$. The separation was still zero up to $25 \mathrm{~min}$ by adding $0.5 \mathrm{mg} \mathrm{L}^{-1}$ $\mathrm{NaBH}_{4}$ meaning that $\mathrm{Fe}(\mathrm{II})$ is not oxidized. The data showed complete separation of $\mathrm{Fe}(\mathrm{III})$ up to $0.6 \mathrm{mg} \mathrm{L}^{-1} \mathrm{NaBH}_{4}$. The separation of $\mathrm{Fe}(\mathrm{III})$ decreases after $0.6 \mathrm{mg} \mathrm{L}^{-1} \mathrm{NaBH}_{4}$ indicating partial reduction of Fe(III) to Fe(II). Figure 7 showes the effect of $\mathrm{NaBH}_{4}$ concentrations on the separation of $\mathrm{Fe}(\mathrm{II})$ and Fe(III), $2 \times 10^{-5} \mathrm{~mol} \mathrm{~L}^{-1}$ each, in presence of $2 \times 10^{-4} \mathrm{~mol} \mathrm{~L}^{-1}$ aluminon using $2 \times 10^{-3} \mathrm{~mol} \mathrm{~L}^{-1} \mathrm{HOL}$ at $\mathrm{pH} \approx 3$. In $\mathrm{Fe}(\mathrm{II})$ the separation was still zero up to $0.6 \mathrm{mg} \mathrm{L}^{-1} \mathrm{NaBH}_{4}$ and increases due to partial oxidation. In conclusion, the mixture of Fe(III)/Fe(II) was separated using $0.6 \mathrm{mg} \mathrm{L}^{-1} \mathrm{NaBH}_{4}$ after adjusting the optimum conditions. 
Table 3. Simultaneous separation and determination of equal and different concentrations of Fe(III) and Fe(II) covering the range from $2 \times 10^{-5}-5 \times 10^{-4}$ mol $\mathrm{L}^{-1}$ $\left(1.12-27.9 \mathrm{mg} \mathrm{L}^{-}\right)$in the presence of $0.5 \mathrm{mg} \mathrm{L}^{-1} \mathrm{NaBH}_{4}, 2 \times 10^{-4} \mathrm{~mol} \mathrm{~L}^{-1}$ aluminon and $2 \times 10^{-3} \mathrm{~mol} \mathrm{~L}^{-1} \mathrm{HOL}$ at $\mathrm{pH} \approx 2 *$.

\begin{tabular}{|c|c|c|c|c|c|c|c|}
\hline \multirow{2}{*}{ Ion } & \multicolumn{2}{|c|}{ Concentration, $\mathrm{mg} \mathrm{L}^{-1}$} & \multirow{2}{*}{$\mathbf{A E}$} & \multirow{2}{*}{$\mathbf{R E}$} & \multirow{2}{*}{ SD } & \multirow{2}{*}{$\Delta$} & \multirow{2}{*}{ Mean recovery, \% } \\
\hline & Added & Found & & & & & \\
\hline$\overline{\mathrm{Fe}(\mathrm{III})}$ & 1.12 & 1.10 & -0.02 & -1.79 & 0.016 & 1.400 & $100 \pm 0.02$ \\
\hline $\mathrm{Fe}(\mathrm{II})$ & 1.12 & 1.13 & 0.01 & 0.89 & $7.070 \times 10^{-3}$ & 0.600 & $100 \pm 0.01$ \\
\hline $\mathrm{Fe}(\mathrm{III})$ & 2.79 & 2.77 & -0.02 & -0.72 & $7.07 \times 10^{-3}$ & 0.570 & $100 \pm 0.01$ \\
\hline $\mathrm{Fe}(\mathrm{II})$ & 2.79 & 2.79 & 0.00 & 0.00 & 0.016 & 0.250 & $100 \pm 0.01$ \\
\hline $\mathrm{Fe}(\mathrm{III})$ & 5.58 & 5.59 & 0.01 & 0.179 & 0.010 & 0.179 & $100 \pm 0.01$ \\
\hline $\mathrm{Fe}(\mathrm{II})$ & 5.58 & 5.57 & -0.01 & -0.179 & 0.010 & 0.179 & $100 \pm 0.01$ \\
\hline $\mathrm{Fe}(\mathrm{III})$ & 1.12 & 1.14 & 0.02 & 1.79 & $7.070 \times 10^{-3}$ & 0.600 & $100 \pm 0.02$ \\
\hline $\mathrm{Fe}(\mathrm{II})$ & 5.58 & 5.56 & -0.02 & -0.36 & 0.017 & 0.300 & $100 \pm 0.02$ \\
\hline $\mathrm{Fe}(\mathrm{III})$ & 2.79 & 2.77 & -0.02 & -0.70 & 0.030 & 1.100 & $100 \pm 0.02$ \\
\hline $\mathrm{Fe}(\mathrm{II})$ & 5.58 & 5.58 & 0.00 & 0.00 & 0.010 & 0.180 & $100 \pm 0.01$ \\
\hline $\mathrm{Fe}(\mathrm{III})$ & 1.12 & 1.11 & -0.01 & -0.89 & 0.020 & 1.790 & $100 \pm 0.01$ \\
\hline $\mathrm{Fe}(\mathrm{II})$ & 27.90 & 27.70 & -0.02 & -0.07 & 0.020 & 0.070 & $100 \pm 0.01$ \\
\hline
\end{tabular}

* AE: Absolute error; RE: Relative error; SD: Standard deviation.

Table 4. Separation and determination of Fe(III) and Fe(II) from synthetic mixtures containing different interferents using $2 \times 10^{-4} \mathrm{~mol} \mathrm{~L}^{-1}$ aluminon, 0.5 ppm $\mathrm{NaBH}_{4}$ and $2 \times 10^{-3} \mathrm{~mol} \mathrm{~L}^{-1} \mathrm{HOL}$ at $\mathrm{pH} \approx 2 *$

\begin{tabular}{|c|c|c|c|c|c|c|c|c|}
\hline \multirow{2}{*}{$\begin{array}{l}\text { Synthetic mixture, } \\
100 \text { ppm for each element }\end{array}$} & \multirow{2}{*}{ Ion } & \multicolumn{2}{|c|}{ Analyte, $\mathrm{mg} \mathrm{L}^{-1}$} & \multirow{2}{*}{$\mathbf{A E}$} & \multirow{2}{*}{$\mathbf{R E}$} & \multirow{2}{*}{ SD } & \multirow{2}{*}{$\Delta$} & \multirow{2}{*}{ Mean recovery, $\%$} \\
\hline & & Added & Found & & & & & \\
\hline \multirow{2}{*}{$\mathrm{Cu}(\mathrm{II})+\mathrm{Pb}(\mathrm{II})+\mathrm{Ni}(\mathrm{II})$} & Fe (II) & 1.12 & 1.10 & -0.02 & -1.79 & 0.017 & 1.50 & $100 \pm 0.02$ \\
\hline & $\mathrm{Fe}$ (III) & 1.12 & 1.09 & -0.03 & -2.70 & $7.070 \times 10^{-3}$ & 0.60 & $100 \pm 0.01$ \\
\hline \multirow{2}{*}{$\mathrm{Hg}(\mathrm{II})+\mathrm{Ca}(\mathrm{II})+\mathrm{Te}(\mathrm{II})$} & $\mathrm{Fe}(\mathrm{II})$ & 1.12 & 1.12 & 0.00 & 0.00 & 0.010 & 0.89 & $100 \pm 0.01$ \\
\hline & $\mathrm{Fe}$ (III) & 1.12 & 1.14 & 0.02 & 1.79 & $7.070 \times 10^{-3}$ & 0.60 & $100 \pm 0.01$ \\
\hline \multirow{2}{*}{$\mathrm{Pb}(\mathrm{II})+\mathrm{Ag}(\mathrm{I})+\mathrm{Cd}(\mathrm{II})$} & $\mathrm{Fe}(\mathrm{II})$ & 1.12 & 1.13 & 0.01 & 0.89 & 0.010 & 0.89 & $100 \pm 0.01$ \\
\hline & $\mathrm{Fe}$ (III) & 1.12 & 1.14 & 0.02 & 1.79 & $0.010 \times 10^{-4}$ & $8.90 \times 10^{-3}$ & $100 \pm 0.01$ \\
\hline \multirow{2}{*}{$\mathrm{La}(\mathrm{III})+\mathrm{Cd}(\mathrm{II})+\mathrm{Mg}(\mathrm{II})$} & $\mathrm{Fe}(\mathrm{II})$ & 1.12 & 1.10 & -0.02 & -1.79 & 0.020 & 1.89 & $100 \pm 0.02$ \\
\hline & $\mathrm{Fe}$ (III) & 1.12 & 1.11 & -0.01 & -0.89 & $5.000 \times 10^{-5}$ & $4.46 \times 10^{-3}$ & $100 \pm 0.01$ \\
\hline
\end{tabular}

*AE: Absolute error; RE: Relative error; SD: Standard deviation.

Table 5. Analysis of Fe(III) in real samples at the recommended conditions *

\begin{tabular}{|c|c|c|c|c|c|c|}
\hline \multirow{2}{*}{ Sample } & \multicolumn{2}{|c|}{ Analyte, \% } & \multirow{2}{*}{$\mathbf{A E}$} & \multirow[b]{2}{*}{$\mathbf{R E}$} & \multirow[b]{2}{*}{ SD } & \multirow{2}{*}{$\Delta$} \\
\hline & Certified & Found & & & & \\
\hline 1-Lead-Zinc sulfide ore. & 6.09 & 6.090 & 0.000 & 0.000 & 0.010 & 0.16 \\
\hline 2-Stream Sediment & 19.71 & 19.713 & 0.003 & 0.020 & 0.010 & 0.05 \\
\hline
\end{tabular}

* AE: Absolute error; RE: Relative error; SD: Standard deviation.

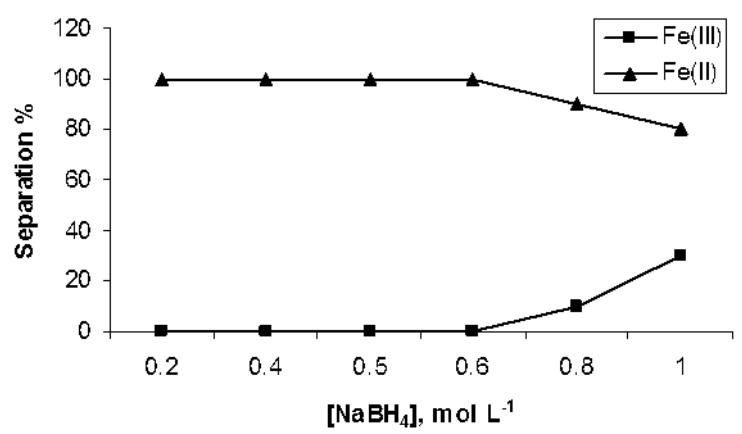

Figure 7. Effect of $\left[\mathrm{NaBH}_{4}\right]$ on the separation efficiency of a mixture of $2 \times 10^{-5} \mathrm{~mol} \mathrm{~L}^{-1} \mathrm{Fe}(\mathrm{III})$ and $\mathrm{Fe}(\mathrm{II})$, each in presence of $2 \times 10^{-4} \mathrm{~mol} \mathrm{~L}^{-1}$ aluminon using $2 \times 10^{-3} \mathrm{~mol} \mathrm{~L}^{-1} \mathrm{HOL}$ and at $\mathrm{pH} \approx 2$.

\subsection{Applications}

Accurate and precise procedure for AAS determination of $\mathrm{Fe}(\mathrm{III})$ depends on the formation of a deep violet color in the aqueous layer obeying Beers' law. The molar absorptivity was found to be $0.2 \times 10^{5} \mathrm{~L} \mathrm{~mol}^{-1} \mathrm{~cm}^{-1}$. Also, the concentration is easily detected in the aqueous layer (instrumental detection limit is $5 \times 10^{-6} \mathrm{~mol} \mathrm{~L}^{-1}$ ) then making a flotation to this colored complex using HOL. This was achieved by an experiment carried to separate $2 \times 10^{-5} \mathrm{~mol} \mathrm{~L}^{-1} \mathrm{Fe}(\mathrm{III})$ under its optimum conditions in the scum layer from $2 \times 10^{-5} \mathrm{~mol} \mathrm{~L}^{-1} \mathrm{Fe}(\mathrm{II})$ in the mother liquor. After separation, Fe(III) content in the scum layer and Fe(II) content in the mother liquor were determined using FAAS.
The proposed procedure was successfully applied to two synthetic mixtures of $\mathrm{Fe}(\mathrm{III})$ and $\mathrm{Fe}(\mathrm{II})$ with different concentrations. These were introduced into the flotation cell as a method for the separation of Fe(III) and aspirated into AAS Spectrometry for Fe(III) determination against standard Fe(III) solutions covering the range of $2 \times 10^{-5}-5 \times 10^{-4} \mathrm{~mol} \mathrm{~L}^{-1}$ (1.12-27.9 ppm) of Fe(III), Table 3. The procedure was applied to the separation and determination of definite $\mathrm{Fe}(\mathrm{III})$ concentration in four synthetic mixtures containing Fe(III) and some cations (Table 4). Analysis of Fe(III) in real samples under the recommended conditions was shown in Table 5 . Known amount of Fe(III) was added to different water samples and examined by such procedure (Table 6).

\subsection{Separation mechanism of Fe(III)}

Many experimental studies were carried out to approach the proposal mechanism. These data can be summarized in the following points:

(i) The elemental analysis [C: 39.9 (Found 39.9); H: 4.1 (4.1) and Fe: 8.4 (8.3)] and the mass spectrum (Figure 8) of the complex isolated in aqueous layer indicating that the complex has the formula [ $\left.\mathrm{Fe}(\mathrm{L})\left(\mathrm{H}_{2} \mathrm{O}\right)_{2} \mathrm{SO}_{4}\right]$.

(ii) The floated species have the same color (violet) as that isolated in aqueous solution.

(iii) The isolated complexes have the same melting points.

(iv) The two complexes have $\mu_{\text {eff }} \approx 5.6 \mathrm{BM}$ confirming an octahedral structure [26] around the ferric ion. This geometry is also confirmed by reading the electronic spectra of the two complexes. The spectra show the same band (580 nm) but with different intensities. 
Table 6. Recovery of $0.5 \times 10^{-4}$ and $1 \times 10^{-4} \mathrm{~mol} \mathrm{~L}^{-1}$ of Fe(III) added to some natural water samples delivered from different locations after separation flotation using $1 \times 10^{-3} \mathrm{~mol} \mathrm{~L}^{-1}$ of aluminon and $2 \times 10^{-3} \mathrm{~mol} \mathrm{~L}^{-1} \mathrm{HOL}$ at $\mathrm{pH} \approx 3$.

\begin{tabular}{|c|c|c|}
\hline Type of water, location* & Analyte added $\times 10^{-4} \mathrm{~mol} \mathrm{~L}^{-1}$ & Mean recovery \\
\hline \multirow{2}{*}{ Bidistilled water } & 0.5 & $100 \pm 0.01$ \\
\hline & 1.0 & $100 \pm 0.01$ \\
\hline \multirow{2}{*}{ Domestic water } & 0.5 & $100 \pm 0.01$ \\
\hline & 1.0 & $100 \pm 0.2$ \\
\hline \multirow{2}{*}{ Tank water } & 0.5 & $105 \pm 0.5$ \\
\hline & 1.0 & $106 \pm 0.3$ \\
\hline \multirow{2}{*}{ Sea water, Marsi-Matroah } & 0.5 & $105 \pm 0.5$ \\
\hline & 1.0 & $106 \pm 0.4$ \\
\hline \multirow{2}{*}{ Sea water, Ras-Elbar } & 0.5 & $108 \pm 0.2$ \\
\hline & 1.0 & $107 \pm 0.4$ \\
\hline \multirow{2}{*}{ Sea water, Gamasa } & 0.5 & $105 \pm 0.3$ \\
\hline & 1.0 & $105 \pm 0.3$ \\
\hline \multirow{2}{*}{ Sea water, Al-Areash } & 0.5 & $104 \pm 0.4$ \\
\hline & 1.0 & $105 \pm 0.5$ \\
\hline \multirow{2}{*}{ Nile water, Mansoura city } & 0.5 & $112 \pm 0.1$ \\
\hline & 1.0 & $109 \pm 0.2$ \\
\hline \multirow{2}{*}{ Nile water, Talka city (near the power station) } & 0.5 & $129 \pm 0.5$ \\
\hline & 1.0 & $130 \pm 0.5$ \\
\hline \multirow{2}{*}{ Nile water, Damiatta city (near the power station) } & 0.5 & $128 \pm 0.5$ \\
\hline & 1.0 & $131 \pm 0.5$ \\
\hline \multicolumn{3}{|l|}{ Waste water, Talkha power station } \\
\hline (a) & 1.0 & $160 \pm 0.6$ \\
\hline (b) & 1.0 & $150 \pm 0.5$ \\
\hline (c) & 1.0 & $145 \pm 0.7$ \\
\hline (d) & 1.0 & $125 \pm 0.8$ \\
\hline \multicolumn{3}{|l|}{ Waste water, Demiatta power station } \\
\hline (a) & 1.0 & $140 \pm 0.8$ \\
\hline (b) & 1.0 & $125 \pm 0.8$ \\
\hline (c) & 1.0 & $138 \pm 0.9$ \\
\hline (d) & 1.0 & $150 \pm 0.9$ \\
\hline
\end{tabular}

${ }^{*} \mathrm{a}, \mathrm{b}, \mathrm{c}$ and d: different samples at different mean times (about one month) from the same location.

(v) The IR spectral bands for all coordination sites are similar. The band at $1240 \mathrm{~cm}^{-1}$ is due to $v\left(\mathrm{SO}_{4}\right)$ [27] and that at $530 \mathrm{~cm}^{-1}$ is due to (M-O) [28]. It is concluded that the mechanism of flotation proceeds through physical adsorption with the aid of air bubbles. Accordingly, the floated complex structure may be suggested as shown in Scheme 2.

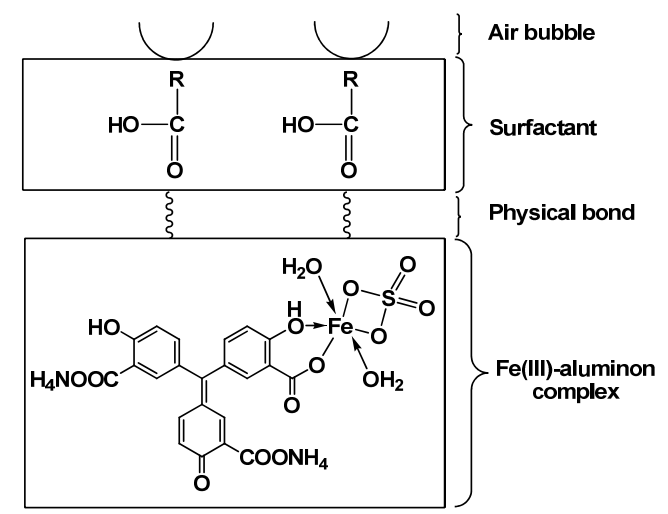

Scheme 2

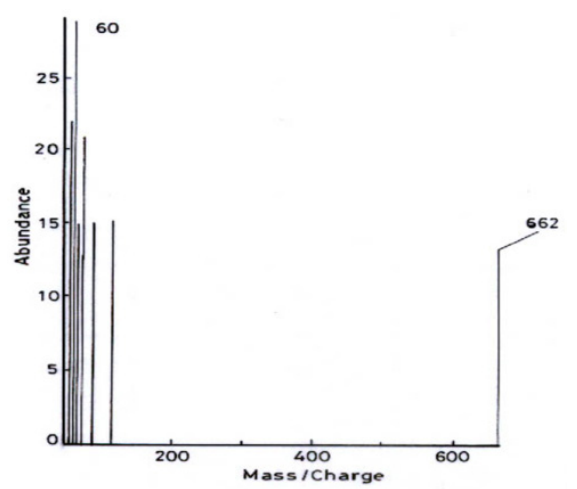

Figure 8. Mass spectrum of Fe(III)-aluminon complex.

\section{References}

[1]. Cotton, F. A.; Wilkinson, G.: Advanced Inorganic Chemistry, 3rd Ed., Wiley, New Delhi, 868, 1972

[2]. Allen, E. A.; Bartlett, P. K. N.; Ingram, G. Analyst 1984, 109, 1075 1080 .

[3]. Allen, J. E.; Spectrochim. Acta 1961, 17(A), 459-466

[4]. Xia, L. B.; Wu, Y. L.; Jiang, Z. C.; Li, S. Q.; Hu, B. Int. J. Environ. Anal. Chem. 2003, 83, 953-962.

[5]. Kara, D.; Alkan M. Talanta 2001. 55, 415-423.

[6]. Pournaghi-Azar, M. H.; Fatemi, B. M. Microchem. J. 2000, 65, 199-207.

[7]. Korkisch, J. Pure Appl. Chem. 1978, 50, 371-378.

[8]. Mizuike, A. Fresenius' Z. Anal. Chem. 1986, 324, 672-677.

[9]. Ghazy, S. E.; El-Asmy, A. A.; El-Nokrashy, A. M. Ind. J. Sci.\& Tech 2008, 1(6), 1-7.

[10]. Rubin, A. J.; Johnson, J. D. Anal. Chem. 1967, 39, 298-302.

[11]. Hiraide, M.; Yoshida, Y.; Mizuike, A. Anal. Chim. Acta 1976, 81, 185 189.

[12]. Hashem, E. Y.; Abu-Baker, M. S.; Hussain, S. M. Spectrochim. Acta 2003, 56(A), 761-769.

[13]. Zaijun, L.; You, F.; Zhongyun, L.; Jian, T. Talanta 2004, 36, 647-651.

[14]. Tarafder, P. K.; Thakur, R. Micrachem. J. 2005, 80, 39-43.

[15]. Sassaki, T.; Mochizuki, K.; Ishiwata, S. Bull. Chem. Soc. Jpn. 1982, 55, 3717-3719.

[16]. Nummela, W.; Iwasaki, I.: Advances in Mineral Processing, Arbiter Symposium, P. Somasundaran (ed.), SME, 1986, 309-342.

[17]. Kadirvelu, K.; Thamordiselvi, K.; Navasivayam, C. Sep. Purif. Technol.2001, 24, 497-505.

[18]. Hasar, H. J. Hazard. Mat. 2003, 97, 49-57.

[19]. Al-Asheh, S.; Duvnjak, Z. Water, Air, Soil Polluion. 1999, 114, 251 276.

[20]. Goksungur, Y.; Uren, S.; Güvenc, U. Bioresource Technol. 2005, 96, 103-109.

[21]. Kim, J. S.; Akeprathumchai, S.; Wickramasinghe, S. R. J. Membr. Sci. 2001, 182, 161-172.

[22]. Blocher, C.; Dorda, J.; Mavrov, V.; Chmiel, H.; Lazaridies, N. K.; Matis, K. A. Water Res. 2003, 37, 4018-4026.

[23]. Veglio, F.; Beolchini, F. Hydrometallurgy 1997, 44, 301-316.

[24]. Vogel, A. I. Text Book of Quantitative Inorganic Analysis, Longmans, London, 1994.

[25]. Laboratory Geological Investigation Ltd., Sofia 1797, G.M. Dimitrov no. 16.

[26]. El-Asmy, A. A.; Al-Gammal, O. A.; Saad, D. A.; Ghazy, S.E .J. Mol. Struc. 2009, 934, 9-22.

[27]. Hassanien, M. M.; Gabr, I. M.; Abdel-Rhman, M. H.; El-Asmy, A. A Spectrochim. Acta 2008, 71(A), 73-79.

[28]. El-Asmy, A. A.; Al-Hazmi, G. A. A. Spectrochim. Acta 2009, 71(A), 1885-1890. 